\title{
Impact of the household environment risk for maintenance of natural foci of Leishmania infantum transmission to human and animal hosts in endemic areas for visceral leishmaniasis in Sao Paulo State, Brazil
}

\author{
Patricia Sayuri Silvestre Matsumoto ${ }^{1}$, Roberto Mitsuyoshi Hiramoto ${ }^{2}$ Virgínia Bodelão Richini \\ Pereira $^{3}$ Valéria Medina Camprigher ${ }^{4}$, Helena Hilomi Taniguchi ${ }^{5}$, José Eduardo de Raeffray \\ Barbosa $^{6}$, Luiz Ricardo Paes de Barros Cortez ${ }^{7}$, Elivelton da Silva Fonseca ${ }^{8}$, Raul Borges \\ Guimarães ${ }^{9}$ and José Eduardo Tolezano ${ }^{10_{*}}$

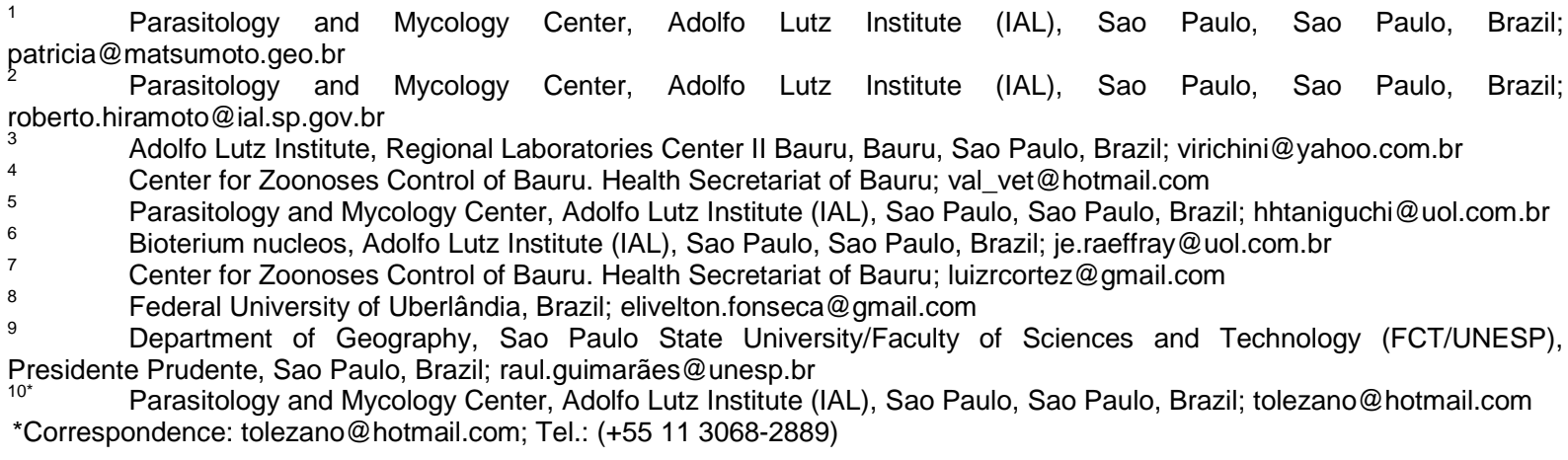

Abstract: When it comes to visceral leishmaniasis $(\mathrm{VL})$ in Brazil, one of the main targets of public health policies of surveillance is the control of domestic canine reservoirs of Leishmania infantum. This paper aims to evaluate the effect of the household environment risk in the maintenance of natural foci and in the transmission to human and animal hosts in an endemic city for VL, Bauru, in Brazil. We collected 6,578 blood samples of dogs living in 3,916 households from Nov.2019 to Mar.2020 and applied geospatial models to predict the disease risk based on the canine population. We used Kernel density estimation, cluster analysis, geostatistics and Generalized Additive Models (GAM). To validate our models, we used cross-validation and created a ROC graph. We found an overall canine VL (CVL) prevalence of $5.6 \%$. Odds ratios $(\mathrm{OR})$ for $\mathrm{CVL}$ increased progressively according to the number of canines for $>2$ dogs (OR 2.70); households that already had CVL in the past increased the chances for CVL currently (OR 2.73); and the cases of CVL increase the chances for human VL cases (OR 1.16). Our models were statistically significant and demonstrated an association between the canine and human disease, mainly in VL foci that remain endemic. Although the Kernel ratio map had the best performance (AUC=82), all the models showed high risk in the city's northwest area. Canine population dynamics must be considered in public policies and geospatial methods may help target priority areas and planning VL surveillance in low and middle-income countries.

Keywords: Vector-borne diseases; disease surveillance and response; visceral leishmaniasis; dogs; spatial modeling; kernel density; geostatistics, generalized additive model; high-risk; public health. 
medRxiv preprint doi: https://doi.org/10.1101/2021.05.18.21257380; this version posted May 22, 2021. The copyright holder for this preprint (which was not certified by peer review) is the author/funder, who has granted medRxiv a license to display the preprint in perpetuity.

It is made available under a CC-BY 4.0 International license .

\section{Highlights}

- Two or more dogs in a household increase the chances for canine visceral leishmaniasis.

- $\quad$ Canine visceral leishmaniasis or households with positive dogs increase the chances for human visceral leishmaniasis.

- Households that already had an infected dog increase the chances for canine visceral leishmaniasis, and it can work as silent endemic areas.

- More than 40 dogs in an area of influence of household (100m buffer) increase the chances for canine and human visceral leishmaniasis.

- $\quad$ Canine population dynamics must be considered in public policies regarding visceral leishmaniasis control in low and middle-income countries.

- $\quad$ Spatial analysis tools can bring new insights into decision-making and public policies regarding visceral leishmaniasis.

\section{Introduction}

Leishmaniasis is a group of infectious diseases caused by a protozoan of the Leishmania genus that affects humans and animals. The transmission occurs by the bite of the dipterous of the subfamily Phlebotominae, the sand flies. It is considered one of the most widely distributed neglected diseases worldwide(1), being a health problem in North and East Africa, West and East Asia, and the Americas(2). More than one billion and a half persons live in risk areas for leishmaniasis around the world. In 2015, between 50 and 90 thousand new cases were estimated per year, with an incidence rate of 2.27 per 100 thousand inhabitants. Only six countries, including Brazil, accounted for about $90 \%$ of all new cases each year(3)(4). From 2005 to 2019, Brazil registered 51,931 cases. In the last update in 2021, Brazil notified a mean of 3,462 human cases of visceral leishmaniasis (VL) in the last 15 years(2).

$\mathrm{VL}$ is a focal disease and its epidemiology differs according to nosogeography entity, which means that different spatial patterns for each species of Leishmania occur, and different strategies for the control of leishmaniasis are demanded. In Latin America, the main reservoir is the domestic dog. 
medRxiv preprint doi: https://doi.org/10.1101/2021.05.18.21257380; this version posted May 22, 2021 . The copyright holder for this preprint (which was not certified by peer review) is the author/funder, who has granted medRxiv a license to display the preprint in perpetuity.

It is made available under a CC-BY 4.0 International license .

However, for control programs, an integrated knowledge about the ecological niche of the vector and environmental conditions is fundamental to address effective measures(5). For this reason, geospatial modeling is a valuable instrument to target interventions of control programs(6).

In Brazil, there is a great difficulty for the effective implementation and operation of the VL control programs (7). Overall, the Brazilian Visceral Leishmaniasis Control Program (VLCP) is based on the control of canine reservoirs, which consists in serosurvey and culling of dogs; control of the vector spraying insecticides inside the households; and early diagnosis and treatment of human cases (8).

The first evidence of VL in Sao Paulo state was the presence of Lutzomyia longipalpis in the urban area of Araçatuba municipality in 1997 (9). In 1998, autochthonous VL dogs were reported, and for the first time in the state, the sand fly was suspected as the vector; and in 1999 autochthonous human cases were reported for the first time (10)(11).

Several factors may be responsible for increasing the cases and the number of deaths in Sao Paulo state, such as difficulty for early diagnosis and specific treatment in human; difficulty in the correct identification and control of domestic reservoirs; and difficulty in controlling the vector population (8). In addition, there is unclear knowledge about other determinants that may influence the design of novel strategies for control and prevention of VL (12).

In Sao Paulo state, Bauru had the first evidence of VL in 2002 when the sandflies were found and the first autochthonous infection in a dog was reported. The first human records occurred in 2003. Since that time, there have been 580 cases and 46 deaths, a lethality rate of $7.9 \%$ from 2003 to 2020(13). The municipality of Bauru was chosen to perform this research because of the high number of cases and its endemicity in the region. In Bauru, there is a lack of information about the spatial distribution and a long-term follow-up of CVL, information that could aid in the global understanding of the problem. The spread of the disease (human cases) came from one cluster in the west to east, and the environmental characteristics suggest a causal relationship of deforestation and human occupation is associated with the emergence of new VL cases (14). Mapping the exact occurrence of the human or canine cases may help better understand the disease and plan public policies regarding VL.

This study aimed to calculate the impact of the household environment risk for visceral leishmaniasis using geospatial methods. We hypothesize that: a) the number of dogs in the 
medRxiv preprint doi: https://doi.org/10.1101/2021.05.18.21257380; this version posted May 22, 2021 . The copyright holder for this preprint (which was not certified by peer review) is the author/funder, who has granted medRxiv a license to display the preprint in perpetuity.

It is made available under a CC-BY 4.0 International license .

households tends to increase human and/or canine VL cases. b) the urban area is stratified by different geographical profiles that allow the remaining endemicity, needing targeted strategies as control measures. Using spatial analysis and statistical approaches, we constructed a space framework based on a large serosurvey conducted between November 2019 and March 2020 in the urban area of Bauru. Of note, there is no existent study using a machine learning-based approach of CVL risk prediction considering the number of dogs. Spatial analysis may be useful to specific interventions to understand VL better.

\section{Materials and Methods}

Bauru is a central municipality of Sao Paulo state $\left(22^{\circ} 18^{\prime} 52^{\prime \prime} \mathrm{S}, 49^{\circ} 03^{\prime} 31^{\prime \prime} \mathrm{W}\right)$, crossed by important highways: SP-300 - Marechal Cândido Rondon Highway, SP-294 - Comandante João Ribeiro de Barros Highway, SP-321 - Cezário José de Castilho Highway, and SP-225 - Engenheiro João Batista Cabral Rennó Highway, giving access to the countryside cities of the state as well to the capital, Sao Paulo.

According to the Köppen-Geiger climate classification updated system (15)(16), Bauru climate is classified as Cfa, which means temperate, without dry season, and with hot Summer. The soil is unsaturated, reddish and dark brown, fine clay sand texture, underlain by sandstone of the Bauru group. The urban areas vegetation is Tropical Semideciduous Forest mixed with Cerrado, highly impacted by urbanization variable patchy pattern. The average altitude of Bauru is $527.4 \mathrm{~m}$.

The population comprises an estimative of 379,297 inhabitants (IBGE, 2020). A research was conducted in 20,958 households in the Sao Paulo state countryside, in which $52.6 \%$ proven dog ownership, with an average of 1.6 dogs at home and an inhabitant ratio of 1:4 dogs per person(18). Following this study, we estimated the dog population at 99,815 , according to the Brazilian Geographic and Statistics Institute (17).

Figure 1: Geospatial location of South America, Brazil, Sao Paulo state, and the serosurvey in Bauru's urban area.

A total of 6,578 blood samples of dogs were analyzed. Points represent each dog's address. Positive dogs for CVL are represented by red dots and negative by blue. Points are overlapped because of the spatial resolution of the cartographic scale.

\subsection{Data sources and Laboratory Diagnostic Tests}

The study analyzed 6,578 samples and surveyed the dog owners from November 2019 to March 2020. Dual-Path Platform rapid test (TR-DPP, Biomanguinhos ${ }^{\circledR}$, Rio de Janeiro, Brazil,) is used 
medRxiv preprint doi: https://doi.org/10.1101/2021.05.18.21257380; this version posted May 22, 2021. The copyright holder for this preprint (which was not certified by peer review) is the author/funder, who has granted medRxiv a license to display the preprint in perpetuity.

It is made available under a CC-BY 4.0 International license .

by the Brazilian VLCP to test the samples. The TR-DPP® is a test for Leishmania infantum based on the reaction of $\lg G$ to the antigen K28. Enzyme Linked Immunosorbent Assay ELISA Biomanguinhos ${ }^{\circledR}$ is used to confirm the diagnoses in the VLCP. It is the reaction of soluble and purified antigens of Leishmania promastigotes, obtained from cultures and adsorbed in microtiter wells with Leishmania-specific antibodies present in serum samples. The diagnostic was run in a Multiscan spectrophotometer using a $450 \mathrm{~nm}$ filter and cutoff values ("Cutoff" = CO): $\mathrm{CO}=$ average negative controls $\times 2$. The diagnoses were performed according to the manufacturer's instructions and the directions of the VLCP.

\subsection{Definition of cases}

A combination of TR DPP® and ELISA reagent was considered a positive result according to the Brazilian VLCP recommendations for canine diagnoses, routinely used by the Centers for zoonoses control in Sao Paulo (19). TR DPP® non-reagent was considered a negative result supplementary material. The prevalence was calculated based on the outcome, being a proportion of a dog found positive for CVL divided by the analyzed dog population. The consent for sample collection involving domestic dogs was provided by the dog owners in the areas surveyed. All serosurvey was supervised by the veterinary group of the Adolfo Lutz Institute in conjunction with the veterinarians responsible for the Center for Zoonoses Control in Bauru municipality. Households without dogs, closed or that refused to give the consent were excluded from the analysis.

The human laboratory diagnoses are based mainly on serological methods and microscopic diagnoses (parasitological). When amastigotes are identified, it is considered a certainty diagnostic. Patients with clinical manifestation and reagent rapid immunochromatographic test rK39 and/or Indirect immunofluorescence with titers equal to or greater than 80 are considered positive for VL (19). Human cases addresses come from the epidemiological surveillance center (CVE) (13).

\subsection{Study design}

Canine data were grouped into the households. The number of dogs was categorized as binary data to verify each risk group: one dog; two dogs; and more than two dogs. Households that already had a positive dog or a human case were also categorized as binary. We considered 1 for cases and 0 for non-cases of VL.

\subsubsection{Mapping}


medRxiv preprint doi: https://doi.org/10.1101/2021.05.18.21257380; this version posted May 22, 2021. The copyright holder for this preprint (which was not certified by peer review) is the author/funder, who has granted medRxiv a license to display the preprint in perpetuity.

It is made available under a CC-BY 4.0 International license .

The addresses of dogs and households were geocoded by an application programming interface (API) of Google Maps (Google $\AA$ ), based on the municipality's cartographic street map. A lower score of geocoding was topologically adjusted to ensure the correction of georeferencing. Point features were plotted in a Geographic Information Systems (GIS) ArcGIS 10.2.2 (ESRI, Imagem). Points (households) were categorized as negative or positive for VL in each survey. Figure 2 shows the mapped data.

Figure 2. Geocoded households of Bauru, stratified by the presence of positive dogs and buffer zones.

The households are identified according to the conducted surveys. Yellow, orange, or red symbols represent the dog's households sampled. Yellow had not an infected dog; orange had an infected dog (in the past); red had and currently has an infected dog. Proportional circles represent the number of dogs in each household. We created a buffer of $100 \mathrm{~m}$ in each sampled household to calculate the number of dogs, positive or negative dogs in this area.

To run the Generalized Additive Model (GAM), we created a fishnet grid of $1000 \times 1000$ of $50 \mathrm{~m}$ containing the number of dogs per domicile in each coordinated. We calculated the number of dogs based on the human population by census tracts (20), in a ratio of 1:4 dogs/inhabitants (18). The mean number of dogs was divided by the mean number of households in each census tract. We then created a centroid and calculated the Inverse distance weighted (IDW) interpolation, considering the mean number of dogs per domicile. The grid values were extracted from the raster surface generated by the IDW - supplementary material.

To analyze the area of influence of households with infected dogs in the environment, we created buffer zones of $100 \mathrm{~m}$ (Figure 2) - supplementary material. We then calculated the number of dogs, negative dogs, and positive dogs using spatial analysis tools. Finally, we aggregated features of point data into polygons, using the census tracts database, to stratify the prevalence spatially.

\subsection{Statistical analysis}

For all the performed calculations, we considered a significant value at $p \leq 0.05$. We used the geographic information system (GIS) ArcGIS 10.2.2 and R language, with several packages described in the sections below.

\subsubsection{Pearson's correlation}

Pearson's correlation was calculated to identify a possible association between the number of cases of CVL and: i) the number of investigated samples or ii) the number of households that 
medRxiv preprint doi: https://doi.org/10.1101/2021.05.18.21257380; this version posted May 22, 2021. The copyright holder for this preprint (which was not certified by peer review) is the author/funder, who has granted medRxiv a license to display the preprint in perpetuity.

It is made available under a CC-BY 4.0 International license .

already had an infected dog, or iii) the number of households that already had and currently have an infected dog/dogs.

\subsubsection{Binary logistic regression}

We tested if the households with an infected dog (outcome $=0$ for a household with no infected dog/dogs or outcome $=1$ for a household with an infected dog/dogs) or an area of influence of household (outcome $=0$ for areas of influence of household with no infected dog/dogs or outcome $=1$ for area of influence of household with infected dog/dogs) could possibly increase the chances to have cases of the disease.

\subsubsection{K-function}

Being aware of spatial dependence of CVL promoting different risks or protection, we evaluate, locally, the spatial interactions in the urban neighborhoods. Ripley's K-function with 999 permutations was applied to identify households' spatial patterns at distances (21). In this function, $\mathrm{K}(\mathrm{t})$ is the number of events within a distance of an arbitrary event, divided by the overall density of events. We plotted maximum and minimal envelopes of the simulated values of $\mathrm{K}(\mathrm{t})$, giving the statistical significance for clustered or dispersed patterns - supplementary material.

\subsubsection{Cluster analysis}

We used cluster analysis to detect significant concentrations of CVL within Confidence Intervals $(\mathrm{Cl})$ of $90 \%, 95 \%$, and $99 \%$ - supplementary material. Clusters were calculated using GetisOrd Gi statistic, which identifies features with either high or low values cluster spatially. The pattern can be expressed by clustered, dispersed, or random features and represents a measurable spatial aggregation unit (ESRI, Imagem).

\subsubsection{Kernel density}

Using the K-funcion dependence, we choose the minimal distance of concentration of our data, $0.5 \mathrm{~km}$, to set the bandwidth. We used the quartic kernel function (22), which is given by

$$
\widehat{\lambda_{\tau}}(\mathrm{s})=\sum_{d_{i} \leq \tau} \frac{3}{\pi \tau^{2}}\left(1-\frac{d_{i}^{2}}{\tau^{2}}\right)^{2}
$$


medRxiv preprint doi: https://doi.org/10.1101/2021.05.18.21257380; this version posted May 22, 2021. The copyright holder for this preprint (which was not certified by peer review) is the author/funder, who has granted medRxiv a license to display the preprint in perpetuity.

It is made available under a CC-BY 4.0 International license .

where:

$i=1, \ldots, n$ are the input points.

$d_{i}$ is the distance between the point $s$ and the observed event in location,

$s_{i}$ and $\tau$ is the radius centered on $s$.

We plotted Kernel density maps for CVL cases and canine samples. A Kernel density ratio map was then performed (CLV: samples), which gives a visualization of the risk for the disease.

\subsubsection{Geostatistical approach}

According to the number of dogs, a geostatistical approach was performed to predict the higher risk areas for CVL. We used the Ordinary Kriging method and select two datasets: cases of CVL and number of dogs. We adjusted data in a stable model in a semivariogram, in which for a set of experimental values $\mathrm{z}(\mathrm{x})$ and $\mathrm{Z}(\mathrm{x} 1+h)$, separated by $h$ distance, is defined by the equation 2 :

$$
\sigma(h)=\frac{1}{2 N(h)} \sum_{i=1}^{N(h)}\left[z\left(x_{i}\right)-z\left(x_{i}+h\right)\right]^{2}
$$

Where,

$N(h)$ is the number of experimental pairs;

$h$ is the regular interval that separates $z(x i)$ e $z\left(x_{i}+h\right)$

Geostatistics parameters were adjusted as follow: number maximum and minimal neighbours= 5 and 2, respectively; lags $=12$; lag size $=0.64$; nugget $=0.46$; range $=3.8974$; sill $=0.062$ and 45 degrees - supplementary material.

\subsubsection{Generalized additive model}

We run a GAM according to an approach reported for case-control data (23)(24), in which we considered $Y_{i}=1$ (cases) and $Y_{i}=0$ (non-cases), $d$ is the number of dogs in location $i$, and $\mathrm{P}\left(\mathrm{Y}_{i}=1 \mid \mathrm{d}_{i} \mathrm{~S}_{i}\right)$ is calculated according to equation 2 :

$$
\operatorname{logit}\left(P_{i}\right)=a+b \times d_{i}+S_{i}
$$

where, 
medRxiv preprint doi: https://doi.org/10.1101/2021.05.18.21257380; this version posted May 22, 2021 . The copyright holder for this preprint (which was not certified by peer review) is the author/funder, who has granted medRxiv a license to display the preprint in perpetuity.

It is made available under a CC-BY 4.0 International license .

$\mathrm{a}$ is the ratio of cases to non-cases,

$\mathrm{b}$ is the coefficient for the number of dogs per household,

$S_{i}$ is a function of the residual spatial variation after accounting for the effect of the number of dogs.

We model $S_{i}$ by a locally estimated scatterplot smoothing (LOESS) regression smoother against the Universal Transverse Mercator coordinates. We choose the optimal smoother parameter of the models based on Akaike's Information Criterion (AIC)(25) after testing multiple bandwidths. We predicted the adjusted log odds for each location and omitted the covariate and smoothing terms through a null model. GAM was run in RStudio (4.0.0) using the 'gam' package, and the grid in ArcGIS 10.2.2.

\subsubsection{Cross-validation}

For further analysis, we validated our data using cross-validation. We created random samples in ArcGIS and then split our database into training (75\%, 2,937 points) and testing (25\%, 979 points). Spatial models were created using the training dataset to predict the risk for the testing dataset. For each model, the best threshold was chosen, and we calculated specificity, sensitivity, and accuracy for correctly predicting the observed value of a case or non-case at the testing coordinates. To sum up, we calculated the area under the receiver operating characteristic (ROC) curve (AUC) with 95\% confidence interval, which plots the true positive rate versus false positive rate, allowing identifying the performance of the models. We used the 'pROC' and 'ggplot2' packages in RStudio.

\section{Results}

The current study investigated 6,578 dogs (Table 1). Anti-Leishmania spp. antibodies were present in $8.1 \%$ of TR DPP $\AA(535 / 6,578)$ and $5.6 \%$ in both TR DPP $\AA$ and ELISA diagnoses $(369 / 6,578)$. We found different spatial prevalence in the investigated census tract, ranging from 0 to $50 \%$, but the mean prevalence was $2.67 \%$. Higher prevalence $(>7.5 \%)$ was regularly distributed in the city in the sampled area (Figure 2).

\subsection{Cluster analysis}

We identified a clustered pattern of households with CVL with statistical significance from approximately 0.5 to $6.5 \mathrm{~km}$ and a clustered pattern of human cases from 0.5 to $4 \mathrm{~km}$ (Figure 3S). 
medRxiv preprint doi: https://doi.org/10.1101/2021.05.18.21257380; this version posted May 22, 2021 . The copyright holder for this preprint (which was not certified by peer review) is the author/funder, who has granted medRxiv a license to display the preprint in perpetuity.

It is made available under a CC-BY 4.0 International license .

Spatially, we found clusters of high values (hot spots) (Figure 3) in west, north, east, south, northeast, southwest, southeast, and in Tibiriçá, a district of the municipality.

Figure 3: Geocoded households of Bauru, stratified by prevalence and cluster analysis.

Each black dot is a household with no identified cluster. Magenta dots are the clusters of domiciles with infected dogs; green dots are the clusters of households that already had infected dogs; and orange dots represent the clusters of households that had and currently have infected dogs. Different size symbols and opacity households were set to ensure the spatial visualization of overlapped households.

The ratio of cases per sample concentration represented in the Kernel map shows high-risk areas in the Pq. Jaraguá, Pq. Santa Edwiges, and Vila Nipônica neighborhoods (Figure 4). Other highrisk concentrations in Kernel's map represent the border effect.

Figure 4: Kernel density for canine visceral leishmaniasis.

Kernel density ratio map ranging from 0 (blue) to 0.7 (red), which gives a visualization of the risk diving the concentration of cases of CVL (Figure 4S) by the concentration of dog samples (Figure 5S). The areas of higher risk are in the west and southwest.

\subsection{Pearson correlation}

Pearson's correlation was positive and moderate considering the number of infected dogs and the households investigated (0.508, $p$-value $=0.000)$; positive low for infected dogs and the households that already had an infected dog/dogs $(0.240, p$-value $=0.000)$; and positive and low for infected dogs and the households that already had and currently have a dog/dogs with VL $(0.129, p$ value $=0.000$ ). All conditions were statistically significant.

\subsection{Binary logistic regression for visceral leishmaniasis}

According to Table 1, 3,916 households were investigated, in which $16.7 \%(656 / 3,916)$ already had a positive dog - independently when it was. Nowadays, $8,7 \%(341 / 3,916)$ of the households have at least one positive dog. From the households with a positive dog/dogs in the past, $17.0 \%(112 / 656)$ still have a positive dog/dogs currently. 
medRxiv preprint doi: https://doi.org/10.1101/2021.05.18.21257380; this version posted May 22, 2021 . The copyright holder for this preprint (which was not certified by peer review) is the author/funder, who has granted medRxiv a license to display the preprint in perpetuity.

It is made available under a CC-BY 4.0 International license .

Table 1: CVL diagnostic, dog count in the households, and buffer zone extraction versus the number of dogs in Bauru.

\begin{tabular}{|c|c|c|c|}
\hline Category & Description & $n$ & $\%$ \\
\hline \multirow{4}{*}{ Diagnoses } & Investigated dogs (samples) & 6,578 & 100 \\
\hline & Reagents samples (TR DPP®) & 535 & 8.1 \\
\hline & Non-reagents samples (TR DPP®) & 6,040 & 91.8 \\
\hline & Positive dogs (reagent for TR DPP® and ELISA) & 369 & 5.6 \\
\hline \multirow{7}{*}{ Households } & \multirow{7}{*}{$\begin{array}{c}\text { Investigated households } \\
\text { Households with only one dog } \\
\text { Households with two dogs } \\
\text { Households with more than two dogs } \\
\text { Households that already had a positive dog/dogs } \\
\text { Households with a positive dog/dogs currently } \\
\text { Households that already had a positive dog/dogs and currently } \\
\text { have positive dog/dogs }\end{array}$} & 3,916 & 100 \\
\hline & & 2,269 & 57.9 \\
\hline & & 1,084 & 27.6 \\
\hline & & 563 & 14.3 \\
\hline & & 656 & 16.7 \\
\hline & & 341 & 8.7 \\
\hline & & 112 & 17.0 \\
\hline \multirow{5}{*}{$\begin{array}{c}\text { area of influence } \\
\text { of household } \\
\text { (buffer of } 100 \mathrm{~m} \text { ) }\end{array}$} & $>0 \leq 10$ dogs & 1,402 & 35.8 \\
\hline & $>10 \leq 20$ dogs & 1,483 & 37.8 \\
\hline & $>20 \leq 30$ dogs & 576 & 14.7 \\
\hline & $>30 \leq 40$ dogs & 248 & 6.3 \\
\hline & $>40 \leq 58$ dogs & 185 & 4.7 \\
\hline
\end{tabular}

Diagnoses summarize the serological diagnoses and the results for investigated dogs; households represent dog's address; the area of influence of household counts the dogs inside a buffer of $100 \mathrm{~m}$ of radios.

The maximum number of dogs per household was 17 , the mean was $(m=1.67)$, with the standard deviation of $\mathrm{SD}=1.08$. In an area of influence of a household ( $a=31,374 \mathrm{~m} 2)$, the maximum number of dogs was 58 , the mean was $m=16$, and the standard deviation $S D=11.37$. Households with only one dog represent almost $60 \%$ of the domiciles, households with two dogs $27.6 \%$, and households with more than three dogs $14 \%$.

The odds ratio (OR) for CVL increased proportionally to the number of dogs (Table 2). The OR for number of dogs examinaded was 1.37. For households with only one dog was 0.40 and increased $242 \%$ for those with two dogs $(\mathrm{OR}=1.39)$; and $97 \%$ when more than two dogs $(\mathrm{OR}=2.70)$. For households that already had a positive dog, the OR was 2.73. OR for the area of influence of household (buffer of $100 \mathrm{~m}$ ) also increased according to the number of dogs. From 10 to 20 dogs, OR was 1.25 and increased $120 \%$ for 21 to 30 dogs $(O R=2.76)$. The influence area of household with more than 30 dogs increased more than $150 \%(\mathrm{OR}>7)$. In an area of influence of household, households that already had a positive dog/dogs with VL increase the chances 299\% (OR=2.99), similarly to the analysis of the households that already had dog/dogs with VL (OR=2.73).

Considering the human cases in an area of influence of household, the number of dogs increased the chances for HVL $102 \%$, and the number of positive dogs $116 \%$, demonstrating the association between canine and human VL. The number of dogs increased the chances $261 \%$ for more than 40 dogs. 
medRxiv preprint doi: https://doi.org/10.1101/2021.05.18.21257380; this version posted May 22, 2021. The copyright holder for this preprint (which was not certified by peer review) is the author/funder, who has granted medRxiv a license to display the preprint in perpetuity.

It is made available under a CC-BY 4.0 International license .

Table 2: Binary logistic regression of Canine Visceral Leishmaniasis diagnostic, dog count in the buffer zone extraction versus the number of positive dogs and human cases in Bauru

\begin{tabular}{ccccc}
\hline & Description & Odds & (95\% Cl) & P-value \\
\hline \multirow{3}{*}{ Rousehold and } & Already had a dog/dogs with VL & 2.73 & $2.14-3.48$ & $0.000^{*}$ \\
CVL & 1 dog/household & 0.40 & $0.32-0.50$ & $0.000^{*}$ \\
& 2 dogs/household & 1.39 & $1.10-1.76$ & $0.006^{*}$ \\
& $>2$ dogs/household & 2.70 & $2.09-3.48$ & $0.000^{*}$ \\
\hline & Number of examined dogs & 1.37 & $1.27-1.48$ & $0.000^{*}$ \\
\hline Area of influence of & Already had a dog/dogs with VL & 2.99 & $2.60-3.44$ & $0.000^{*}$ \\
household (buffer & Number of examined dogs & 1.10 & $1.09-1.11$ & $0.000^{*}$ \\
of 100m) and CVL & $\leq 10$ dogs & 0.23 & $0.20-0.26$ & $0.000^{*}$ \\
& $>10 \leq 20$ dogs & 1.25 & $1.10-1.42$ & $0.001^{*}$ \\
& $>20 \leq 30$ dogs & 2.76 & $2,28-3,35$ & $0.000^{*}$ \\
Area of influence of & $>30 \leq 40$ dogs & 7.73 & $5,25-11,39$ & $0.000^{*}$ \\
household (buffer & $>40 \leq 58$ dogs & 7.29 & $4,69-11.34$ & $0.000^{*}$ \\
of 100m) and & Number of positive dogs & 1.16 & $1.09-1.24$ & $0.000^{*}$ \\
human cases & Number of samples & 1.02 & $1.01-1.02$ & $0.000^{*}$ \\
& $>10$ dogs & 0.75 & $0.64-0.88$ & $0.000^{*}$ \\
& $>10 \leq 20$ dogs & 1.16 & $1.00-1.35$ & 0.053 \\
\hline
\end{tabular}

Dependent variables are CVL and HVL cases. Explanatory variables are the number of dogs, infected dogs, and the condition of the households that already had an infected dog/dogs. *statistical significance.

\subsection{Spatial risk}

Considering high OR for CVL according to the number of dogs, we created the spatial models using the number of dogs as a predictor. Figure 5 shows that both models (geostatistical and GAM) were considerable commonality in the spatial pattern. Higher risk is in the borders of the city, especially in the northwest and in the southeast. The last one can be a border effect. Moreover, both models are consistent with the Kernel density ratio map (Figure 4).

Figure 5: predicting the risk for canine visceral leishmaniasis using geospatial methods.

Spatial prediction of CVL based on the number of dogs. Risk is scaled from low (blue) to high (red), as shown by the legends. (a) Geostatistical approach using the ordinary Kriging method. (b) Generalized additive model.

\subsection{Cross-validation}

Kernel, Geostatistical and GAM models were plotted in the ROC graph (Figure 6). The Kernel ratio presented the best threshold of 0.059 , a sensitivity of $88 \%$, a specificity of $62 \%$ and an accuracy of $64 \%$. Geostatistical model presented the best threshold of 0.075 , a sensitivity of $65 \%$, a specificity of $52 \%$, and an accuracy of $53 \%$. GAM model presented the best threshold of 0.076 , a sensitivity of $88 \%$, a specificity of $19 \%$, and an accuracy of $25 \%$. The first had an AUC of 0.81 (Cl 0.76 - 0.85), the second of $0.59(\mathrm{Cl} 0.53-0.66)$ and the third of $0.54(\mathrm{Cl} 0.47-0.60)$. The Kernel density ratio map presented the best performance in the ROC graph. 
medRxiv preprint doi: https://doi.org/10.1101/2021.05.18.21257380; this version posted May 22, 2021 . The copyright holder for this preprint (which was not certified by peer review) is the author/funder, who has granted medRxiv a license to display the preprint in perpetuity.

It is made available under a CC-BY 4.0 International license.

Graph 1: Area under the receiver operating characteristic (ROC) for canine visceral leishmaniasis.

For each model, the AUC was calculated with 95\% confidence intervals. The best model in predicting canine risk disease was the Kernel density ratio map.

\section{Discussion}

In the current study, we found a CVL TR DPP® sero-reaction rate of $8.1 \%(535 / 6578)$ and $5.6 \%$ in both TR DPP® and ELISA diagnoses (369/6578), likely consistent with an endemic area of Sao Paulo State, Araçatuba, where the average prevalence between 2010 and 2015 was 6.8\% (26). Studies in other states of Brazil found a variable range of values of prevalence, for instance, $4.38 \%$ in Londrina, Paraná (27); 8.1\% in the communities of Cuiabá river(28), and 19.2\% in Rondonópolis(29), both in the State of Mato Grosso; $4.16 \%$ in Belo Horizonte, State of Minas Gerais (30); and a high prevalence of $50.3 \%$ in Buerarema, State of Bahia (31). In Bauru, we found different spatial prevalences, ranging from 0 to $50 \%$. Lamattina et al. (2019) found prevalences per site varying from 0 to $80 \%$ (32) and Carvalho et al. (2018) from 0 to $35 \%(29)$.

Particularly, prevalence can reveal bias once it may not represent the real number of canines. Overall, the serosurveys are directed to human case areas and/or areas of a suspect or identified canine VL case (19)(8). Historically, in Bauru, some neighborhoods have never performed a serosurvey before this study. On the other hand, some neighborhoods were investigated more than once since the first human case appearance, recognized by its recurrence of CVL. Our study planned the serosurvey to collect a large number of dog samples in different neighborhoods, giving a panorama of VL's endemicity and spatial epidemiological profile in a short time. Nevertheless, examined canines comprised less than $7 \%$ of the estimated dog population $(6,578 / 99,815$ dogs).

In the present study, our scale is the household instead of only the dogs, identifying spatial characteristics regarding the domiciles and canine population. We highlight that on the household scale, the positivity index of domiciles with infected dogs $(8.7 \%)$ is superior that the global prevalence of CVL (5.6\%), which emphasizes the importance of the household in the disease context. Clusters of households that already had CVL can point out the areas that remain a source of infection and are unnoticed. Almost all investigated areas had these clusters. Additionally, asymptomatic dogs can be highly competent (33) and remain a source of infection without being identified. They contribute to the silent endemic areas. It can turn out into highly endemic areas or possibly a human case site. Cluster gave us previous information of critical areas regards CVL. 
medRxiv preprint doi: https://doi.org/10.1101/2021.05.18.21257380; this version posted May 22, 2021 . The copyright holder for this preprint (which was not certified by peer review) is the author/funder, who has granted medRxiv a license to display the preprint in perpetuity.

It is made available under a CC-BY 4.0 International license .

The recent expansion of $V L$ to new endemic areas has been attributed to the adaptation of $L$. longipalpis (sandflies) to naïve ecological niches. The risk of expansion of VL increases in areas identified as migratory poles of attraction. Moreover, CVL has been highlighted as the primary cause of outbreaks (34). In these areas, canine enzootic disease precedes the appearance of human cases. In our study, CVL increased the chances $102 \%$ for human cases and $116 \%$ for dogs, demonstrating an association between canine and human VL. Other studies found that the risk increased substantially for individuals when the presence of seropositive dogs (35) or previous cases of CVL in the household (36)(37). Furthermore, we identified a clustered pattern for both human and canine cases from approximately $500 \mathrm{~m}$.

As we identified, households with CVL and the dog population can increase the chances for $\mathrm{VL}$ and maintenance of natural foci of Leishmania infantum transmission to human and animal hosts, which urges specific public policies focused on animal health, especially in areas target as critical. We found the same mean number of dogs per household (1.6), as reported in previous research (18). Less than $15 \%$ of the investigated households have more than 3 dogs, which is the minority, easily to monitor and investigate as a possible infection site. In the neighborhoods where the canine population is large, animal health assistance is required. Therefore, canine population dynamics must be considered in public policies.

Our results revealed that the risk of increasing CVL or human cases oscillated by areas. Of note, kernel maps studies have used the total number of cases or applied a constant(30). Our study used the number of cases and samples, which gives a visualization of the risk. In accordance, (29) used the same methodology and found a similar pattern of critical areas in the city's borders, a pattern that seems to be expected in small and medium-sized cities of similar urbanization process in low and middle-income countries where VL is endemic. The Kernel density ratio map was the best in the ROC graph, showing spatial analysis tools potential.

Spatial models predicting disease risk are promising for decision-making regarding the control of VL. Such studies use machine learning for cutaneous leishmaniasis vectors prediction (38) or human cases prediction (39). Bi et al. stress that future research about VL should focus on spatial simulation and agent-based simulation(40). Machine learning is a novel approach that allows the forecast of disease risk. It can anticipate disease transmission dynamics and identify disease control strategies to fight endemic and emerging diseases (40). Our models bring new insights for thinking VL 
medRxiv preprint doi: https://doi.org/10.1101/2021.05.18.21257380; this version posted May 22, 2021. The copyright holder for this preprint (which was not certified by peer review) is the author/funder, who has granted medRxiv a license to display the preprint in perpetuity.

It is made available under a CC-BY 4.0 International license .

through canines from a social perspective, which has been one of the most debatable points of control programs and tends to be of low priority in the context of general public health.

It is a time of changing public policies in relation to VL. The general principles that guided the past control programs are now questionable. Brazilian VLCP, performed by municipal levels, have presented operational difficulties in executing VL control strategies(41). Additionally, we highlight the unavailability of the proven effectiveness of technical alternatives for laboratory diagnosis, identification, and elimination or protection of reservoirs (42).

In Brazilian cities, culling dogs has been recommended as a control measuring to reduce VL (19)(43), which creates a dog stigma. Culling dogs is highly controversial, considering the time between diagnosis and action; issues from animal protection societies; rapid replacement of euthanized dogs as well the entrance of new animals into the households (44)(45)(46); and the persistent disease spread. Even in the academic environment, culling dogs have been critically discussed $(42,47)(48)(49)$. By contrast, other strategies, such as the use of dog collar with insecticides for sand flies, or vaccination (50)(51)(52), have been highly encouraged due to their effectiveness in reducing the population of vector, parasitic load, and potentially the VL transmission (53)(54)(55)(56).

Vast territorial areas should be treated by priority order, emphasizing different profiles of VL. Furthermore, considering the genetic diversity of vectors (57)(58) and the protozoa (59)(60), even at the local levels, seem to be alternatives to rethink new VL approaches. The decision-making should be supported by an integrated approach, considering education, health, and environment, including vectors, causal agent, canines, households, population density, urbanization, presence of buildings, industries, and environmental factors, such as vegetation, water bodies, temperature, and precipitation. Animal health needs to be discussed in public policies without its stigma. Furthermore, VL should be addressed in the context of One Health (42).

To conclude, this paper had several limitations that should be recognized. Firstly, we had to use the census tract information based on the human population to calculate the canine population grid because of the lack of animal information. This could be solved with an updated canine census, hardly achieved in low and medium-income countries. Secondly, the performance of our spatial models had medium and low accuracy, although the critical areas being commonly similar to the Kernel ratio map of higher performance, which emphasizes a high chance that the classifier distinguishes the positive class values from the negative. The better performance of the models could 
medRxiv preprint doi: https://doi.org/10.1101/2021.05.18.21257380; this version posted May 22, 2021 . The copyright holder for this preprint (which was not certified by peer review) is the author/funder, who has granted medRxiv a license to display the preprint in perpetuity.

It is made available under a CC-BY 4.0 International license .

be improved with an updated census and adding real-world covariates when data become available.

There are still research gaps concerning VL, and many areas of study remain unexplored. It remains the question of balancing the effectiveness and costs involved in such a VL control plan (40). As future work, the next step of our research is to analyze the canines' role with new insights of controlling VL, for instance, canine cohort studies of insecticide-impregnated collars, vaccination, and treatment in different areas of this endemic site, as an individual and collective measure in the environment.

\section{Conclusions}

As a rule of thumb, one can say that the number of canines and the households impact the risk for maintenance of natural foci of Leishmania infantum transmission to human and animal hosts in endemic areas for VL. Overall, this study serves as a case study for regional and global applications. It reveals the importance of canines on the household scale in low and middle-income countries. It is time for changing VL public policies using a targeted plan of priority through spatial analysis. This statement invites further investigations regarding VL characteristics involving socioeconomic and environmental variables and $\mathrm{VL}$ in one health context.

\section{Abbreviations}

API - application programming interface

CVE $=$ epidemiological surveillance center

$\mathrm{CVL}=$ canine visceral leishmanisis

ELISA = Enzyme-linked immunosorbent assay

GAM = generalized additive model

GIS = geographic information system

$H V L=$ human visceral leishmanisis

IDW = inverse distance weighted

$\mathrm{OR}=$ odds ratio

TR-DPP = rapid test dual-path plataform

$\mathrm{VL}=$ visceral leishmaniasis

VLCP = Brazilian visceral leishmaniasis surveillance and control program 
medRxiv preprint doi: https://doi.org/10.1101/2021.05.18.21257380; this version posted May 22, 2021. The copyright holder for this preprint (which was not certified by peer review) is the author/funder, who has granted medRxiv a license to display the preprint in perpetuity.

It is made available under a CC-BY 4.0 International license .

\section{Funding}

This research was funded by Sao Paulo Research Foundation (FAPESP): grant number: "2019/22246-8", "2018/25889-4", and GAPS/FESIMA (Grupo de Apoio às Políticas de Prevenção e Proteção à Saúde/Fundo Especial de Saúde para Imunização em Massa e controle de Doenças) grant number 2019/01057.

\section{Authors' contributions}

Conceptualization, P.S.S.M.; J.E.T.; methodology, P.S.S.M; R.M.H; V.B.R.P.; H.H.T.; V.M.C.; software, P.S.S.M.; validation, P.S.S.M.; E.S.F.; R.B.G.; formal analysis, P.S.S.M.; investigation, P.S.S.M.; V.B.R.P.; J.E.T.; resources, P.S.S.M.; J.E.T; data curation, P.S.S.M.; writing—original draft preparation, P.S.S.M.; J.E.T; E.S.F.; writing—review and editing, P.S.S.M.; R.M.H.; V.B.R.P.; V.M.C.; H.H.T.; J.E.R.B.; L.R.P.B.C.; E.S.F.; R.B.G.; J.E.T.; visualization, P.S.S.M; supervision, J.E.T.; project administration, J.E.T.; funding acquisition, J.E.T. All authors have read and agreed to the published version of the manuscript.

\section{Acknowledgments}

We thank Center for Zoonoses Control staff: Aline Fernanda Peral Cano, Cláudia Cilene Barbosa Gomieri, Josiane Silva Cano, Maria Emília Bodini Santiago, Roldão Antônio Puci Neto; Adolfo Lutz Institute students and staff: Aghata Regina de Oliveira Alves Palmeira; Amanda Gonçalves Martins da Costa; Alessandra Ventura Santos, Luana Ribeiro Manzi, Naíra Ruiz Lenharo, Maria Cristina de Carvalho; Graphical abstract was created with BioRender.com.

\section{Ethical statement}

This study was approved under number 03/2000 in Ethics Committee on the Use of Animals in Research at the Adolfo Lutz Institute, Sao Paulo-SP, Brazil.

\section{Competing interests}

The authors declare that they have no competing interests. 
medRxiv preprint doi: https://doi.org/10.1101/2021.05.18.21257380; this version posted May 22, 2021. The copyright holder for this preprint (which was not certified by peer review) is the author/funder, who has granted medRxiv a license to display the preprint in perpetuity.

It is made available under a CC-BY 4.0 International license .

\section{References}

1. WHO. Control of the Leishmaniases. WHO Expert Comm Control Leishmaniases, Geneva, 22-26 March 2010 [Internet]. 2010;(March):22-6. Available from: http://apps.who.int/iris/bitstream/10665/44412/1/WHO_TRS_949_eng.pdf

2. WHO. Leishmaniasis, number of cases of visceral leishmaniasis reported [Internet]. 2021. p. 27-8. Available from: WHO 2020. https://www.who.int/data/gho/data/indicators/indicator-details/GHO/numberof-cases-of-visceral-leishmaniasis-reported

3. Wamai RG, Kahn J, McGloin J, Ziaggi G. Visceral leishmaniasis: a global overview. J Glob Heal Sci. $2020 ; 2(1): 1-22$.

4. Pasquali AKS, Baggio RA, Boeger WA, González-Britez N, Guedes DC, Chaves EC, et al. Dispersion of Leishmania (Leishmania) infantum in central-southern Brazil: Evidence from an integrative approach. PLoS Negl Trop Dis. 2019;13(8):1-20.

5. Peterson AT, Pereira RS, Camargo-Neves VF. Using epidemiological survey data to infer geographic distributions of leishmaniasis vector species. Rev Soc Bras Med Trop. 2004;37(1):10-4.

6. Pigott DM, Golding N, Messina JP, Battle KE, Duda KA, Balard Y, et al. Global database of leishmaniasis occurrence locations, 1960-2012. Sci Data. 2014;1:1-7.

7. Harhay MO, Olliaro PL, Costa DL, Costa CHN. Urban parasitology: Visceral leishmaniasis in Brazil. Trends Parasitol [Internet]. 2011;27(9):403-9. Available from: http://dx.doi.org/10.1016/j.pt.2011.04.001

8. BRASIL. Manual de Vigilância e Controle da Leishmaniose Visceral [Internet]. Brasília; 2014 [cited 2015 Jan 20]. p. 120. Available from:

http://bvsms.saude.gov.br/bvs/publicacoes/manual_vigilancia_controle_leishmaniose_visceral_1edicao.p df

9. Costa AIP da, Casanova C, Rodas LAC, Galati EAB. Atualização da distribuição geográfica e primeiro encontro de Lutzomyia longipalpis em área urbana no Estado de São Paulo, Brasil. J Public Health (Bangkok). 1997;31(6):535-41.

10. Camargo-Neves VLF De, Katz G, Rodas LAC, Poletto DW, Lage LC, Spínola RMF, et al. Utilização de ferramentas de análise espacial na vigilância epidemiológica de leishmaniose visceral americana Araçatuba, São Paulo, Brasil, 1998-1999. Cad Saude Publica [Internet]. 2001;17(5):1263-7. Available from: http://www.scielo.br/scielo.php?pid=S0102-311X2001000500026\&script=sci_arttext

11. Tolezano JE, Taniguchi HH, Araújo MDFL, Barbosa JADR, Barbosa JEDR, Luvizotto MC, et al. Leishmaniose Visceral Americana em Araçatuba, região oeste do Estado de são Paulo. Investigações laboratoriais e diagnóstico etiológico de uma doença emergente no estado de São Paulo. In: 35 Congresso da sociedade Brasileira de Medicina Tropical, 1999, Guarapari Revista da sociedade 
medRxiv preprint doi: https://doi.org/10.1101/2021.05.18.21257380; this version posted May 22, 2021. The copyright holder for this preprint (which was not certified by peer review) is the author/funder, who has granted medRxiv a license to display the preprint in perpetuity.

It is made available under a CC-BY 4.0 International license .

Brasileira de Medicina Tropical, 1999. 1999. p. 9-39.

12. Moreira ED, De Souza VMM, Sreenivasan M, Lopes NL, Barreto RB, De Carvalho LP. Peridomestic risk factors for canine leishmaniasis in urban dwellings: New findings from a prospective study in Brazil. Am J Trop Med Hyg. 2003;69(4):393-7.

13. CVE. Centro de Vigilância Epidemiológica "Prof. Alexandre Vranjac" [Internet]. Centro de Vigilância Epidemiológica. CVE,2021. Available from < http://www.saude.sp.gov.br/cve-centro-de-vigilanciaepidemiologica-prof.-alexandre-vranjac/areas-de-vigilancia/doencas-de-transmissao-por-vetores-ezoonoses/agravos/leishmaniose-visceral/dados-estatisticos>. 7 may 2021.

14. Souza VAF, Cortez LRPB, Dias RA, Amaku M, Neto JSF, Kuroda RBS, et al. Space-time cluster analysis of American visceral leishmaniasis in Bauru, São Paulo State, Brazil. Cad Saude Publica. 2012;28(10):1949-64.

15. Peel MC, Finlayson BL, McMahon TA. Updated world map of the Köppen-Geiger climate classification. Hydrol Earth Syst Sci. 2007;11(5):1633-44.

16. Alvares CA, Stape JL, Sentelhas PC, De Moraes Gonçalves JL, Sparovek G. Köppen's climate classification map for Brazil. Meteorol Zeitschrift. 2013;22(6):711-28.

17. IBGE. Brazilian Institute of Geography and Statistics [Internet]. 2010 [cited 2016 Oct 14]. Available from: http://www.ibge.gov.br/english/

18. Alves MCGP, Matos MR de, Reichmann MDL, Dominguez MH. Estimation of the dog and cat population in the State of São Paulo. Rev Saude Publica [Internet]. 2005;39(6):891-7. Available from: http://www.scielo.br/pdf/rsp/v39n6/en_26982.pdf

19. Ministério da Saúde do Brasil. Guia de vigilância em saúde $3^{\mathrm{a}}$ edição [Internet]. BRASIL, Ministério da Saúde.Secretaria de Vigilância em Saúde. Coordenação-Geral de Desenvolvimento da Epidemiologia em Serviços. 2019. 741 p. Available from:

http://portal.anvisa.gov.br/documents/33852/3507912/Caderno+3+-

+Critérios+Diagnósticos+de+Infecção+Associada+à+Assistência+à+Saúde+Neonatologia/9fa7d9be6d35-42ea-ab48-bb1e068e5a7d

20. Matsumoto PSS, Flores EF, Barbosa JS, Pessoto UC, Tolezano, José Eduardo Hiramoto, Roberto Mitsuyoshi Taniguchi HH, Guimarães RBG. The path of canine visceral leishmaniasis versus the path of Center for Zoonoses Control: contributions of spatial analysis to health. Reports Public Heal. 2021 ;printing p.

21. Dixon PM. Ripley's K function Theoretical K ( t ) function. Statistics (Ber). 2014;(December):1-16.

22. Bailey TC, Gatrell AC. Interactive spatial data analysis. New York: Longman; 1995. 413 p.

23. Baker S, Holt KE, Clements ACA, Karkey A, Arjyal A, Boni MF, et al. Combined high-resolution genotyping and geospatial analysis reveals modes of endemic urban typhoid fever transmission. Open 
medRxiv preprint doi: https://doi.org/10.1101/2021.05.18.21257380; this version posted May 22, 2021. The copyright holder for this preprint (which was not certified by peer review) is the author/funder, who has granted medRxiv a license to display the preprint in perpetuity.

It is made available under a CC-BY 4.0 International license .

Biol. 2011;1(OCTOBER).

24. Webster T, Vieira V, Weinberg J, Aschengrau A. Method for mapping population-based case-control studies: An application using generalized additive models. Int J Health Geogr. 2006;5:1-10.

25. Baker S, Holt KE, Clements ACA, Karkey A, Arjyal A, Boni MF, et al. Combined high-resolution genotyping and geospatial analysis reveals modes of endemic urban typhoid fever transmission. Open Biol. 2011;1(OCTOBER).

26. Costa DNCC, Bermudi PMM, Rodas LAC, Nunes CM, Hiramoto RM, Tolezano JE, et al. Human visceral leishmaniasis and relationship with vector and canine control measures. Cad Saude Publica. 2018;52(92):1-11.

27. Benitez A do N, Martins FDC, Mareze M, Nino B de SL, Caldart ET, Ferreira FP, et al. Spatial and simultaneous seroepidemiology of anti-Leishmania spp. antibodies in dog owners and their dogs from randomly selected households in a major city of southern Brazil. Prev Vet Med. 2018 Jun 1;154:47-53.

28. Franco Sousa VR, De Lima Ruy Dias ÁF, Rodrigues JY, De Medeiros Torres M, Assunção Rosa Moreira JM, Nakazato L, et al. Canine visceral leishmaniasis in riverside communities of the Cuiabá river watershed. Semin Agrar. 2019;40(6):3313-9.

29. Carvalho AG de, Luz JGG, Rodrigues LD, Dias JVL, Fontes CJF. High seroprevalence and peripheral spatial distribution of visceral leishmaniasis among domestic dogs in an emerging urban focus in Central Brazil: a cross-sectional study. Pathog Glob Health [Internet]. 2018;112(1):29-36. Available from: http://doi.org/10.1080/20477724.2018.1438229

30. de Arruda RMF, Cardoso DT, Teixeira-Neto RG, Barbosa DS, Ferraz RK, Morais MHF, et al. Space-time analysis of the incidence of human visceral leishmaniasis $(\mathrm{VL})$ and prevalence of canine $\mathrm{VL}$ in a municipality of southeastern Brazil: Identification of priority areas for surveillance and control. Acta Trop [Internet]. 2019;197(March):105052. Available from: https://doi.org/10.1016/j.actatropica.2019.105052

31. Leça Júnior NF, Guedes PEB, Santana LN, Almeida V dos A, Carvalho FS, Albuquerque GR, et al. Epidemiology of canine leishmaniasis in southern Bahia, Brazil. Acta Trop. 2015;148:115-9.

32. Lamattina D, Berrozpe PE, Casas N, Moya SL, Giuliani MG, Costa SA, et al. Twice upon a time: The progression of canine visceral leishmaniasis in an Argentinean city. PLoS One. 2019;14(7):1-18.

33. Laurenti MD, Rossi CN, Matta VLR da, Tomokane TY, Corbett CEP, Secundino NFC, et al. Asymptomatic dogs are highly competent to transmit Leishmania (Leishmania) infantum chagasi to the natural vector. Vet Parasitol. 2013;196(3-4):296-300.

34. Teixeira-Neto R, da Silva E, Nascimento R, Belo V, de Oliveira C, Pinheiro L, et al. Canine visceral leishmaniasis in an urban setting of Southeastern Brazil: an ecological study involving spatial analysis. Parasit Vectors [Internet]. 2014;7(1):485. Available from:

http://www.parasitesandvectors.com/content/7/1/485 
medRxiv preprint doi: https://doi.org/10.1101/2021.05.18.21257380; this version posted May 22, 2021. The copyright holder for this preprint (which was not certified by peer review) is the author/funder, who has granted medRxiv a license to display the preprint in perpetuity.

It is made available under a CC-BY 4.0 International license .

35. Costa DNCC, Blangiardo M, Rodas LAC, Nunes CM, Hiramoto RM, Tolezano JE, et al. Canine visceral leishmaniasis in Araçatuba, state of São Paulo, Brazil, and its relationship with characteristics of dogs and their owners: A cross-sectional and spatial analysis using a geostatistical approach. BMC Vet Res. 2018;14(1):1-13.

36. Coura-Vital W, Reis AB, Reis LES, Braga SLÔ, Roatt BM, Aguiar-Soares RD de O, et al. Canine visceral leishmaniasis: Incidence and risk factors for infection in a cohort study in Brazil. Vet Parasitol [Internet]. 2013;197(3-4):411-7. Available from: http://dx.doi.org/10.1016/j.vetpar.2013.07.031

37. Chapman LAC, Jewell CP, Spencer SEF, Pellis L, Datta S, Chowdhury R, et al. The role of case proximity in transmission of visceral leishmaniasis in a highly endemic village in Bangladesh. PLoS Negl Trop Dis. 2018;12(10):e0006453.

38. Mollalo A, Sadeghian A, Israel GD, Rashidi P, Sofizadeh A, Glass GE. Machine learning approaches in GIS-based ecological modeling of the sand fly Phlebotomus papatasi, a vector of zoonotic cutaneous leishmaniasis in Golestan province, Iran. Acta Trop. 2018;188(July):187-94.

39. Ding F, Wang Q, Fu J, Chen S, Hao M, Ma T, et al. Risk factors and predicted distribution of visceral leishmaniasis in the Xinjiang Uygur Autonomous Region, China, 2005-2015. Parasites and Vectors [Internet]. 2019;12(1):1-10. Available from: https://doi.org/10.1186/s13071-019-3778-z

40. Bi K, Chen Y, Zhao S, Kuang Y, John Wu CH. Current Visceral Leishmaniasis Research: A Research Review to Inspire Future Study. Biomed Res Int. 2018;2018.

41. von Zuben APB, Donalísio MR. Dificuldades na execução das diretrizes do Programa de Vigilância e Controle da Leishmaniose Visceral em grandes municípios brasileiros. Cad Saude Publica [Internet]. 2016;32(6):1-11. Available from: http://www.scielo.br/scielo.php?script=sci_arttext\&pid=S0102$311 \times 2016000600401 \& \operatorname{lng}=p t \&$ tlng=pt

42. Dantas-Torres F, Miró G, Baneth G, Bourdeau P, Breitschwerdt E, Capelli G, et al. Canine leishmaniasis control in the context of one health. Emerg Infect Dis. 2019;25(12):E1-4.

43. Brasil. Manual de Vigilância e Controle da Leishmaniose Visceral - Ministério da Saúde [Internet]. Brasília; 2006. Available from: ftp://ftp.cve.saude.sp.gov.br/doc_tec/zoo/lva06_manual.pdf

44. Nunes CM, Lima VMF de, Paula HB de, Perri SHV, Andrade AM de, Dias FEF, et al. Dog culling and replacement in an area endemic for visceral leishmaniasis in Brazil. Vet Parasitol. 2008;153(1-2):19-23.

45. Costa DNCC, Codeço CT, Silva MA, Werneck GL. Culling Dogs in Scenarios of Imperfect Control: Realistic Impact on the Prevalence of Canine Visceral Leishmaniasis. PLoS Negl Trop Dis. 2013;7(8).

46. Wilke VML. Avaliação das atividades de controle da Leishmaniose visceral canina no município de Sabará, Minas Gerais, 1995 a 2000. Universidade Federal de Minas Gerais; 2005.

47. Dantas-Torres F, Miró G, Bowman DD, Gradoni L, Otranto D. Culling Dogs for Zoonotic Visceral Leishmaniasis Control: The Wind of Change. Trends Parasitol [Internet]. 2019;35(2):97-101. Available 
medRxiv preprint doi: https://doi.org/10.1101/2021.05.18.21257380; this version posted May 22, 2021 . The copyright holder for this preprint (which was not certified by peer review) is the author/funder, who has granted medRxiv a license to display the preprint in perpetuity.

It is made available under a CC-BY 4.0 International license .

from: http://dx.doi.org/10.1016/j.pt.2018.11.005

48. Machado CJS, Silva EG, Vilani RM. Use of an instrument of controversial public health policy: Euthanasia of dogs contaminated by leishmaniasis in Brazil. Saude e Soc. 2016;25(1):247-58.

49. Donato LE, Lima Júnior FEF de, Alburquerque R, Gomes MLS. Vigilância e controle de reservatórios da leishmaniose visceral no Brasil: aspectos técnicos e jurídicos. Rev Educ Contin em Med Veterinária e Zootec do CRMV-SP. 2013;11(2):18-23.

50. Palatnik-de-Sousa CB, Day MJ. One Health: The global challenge of epidemic and endemic leishmaniasis. Parasit Vectors. 2011;4(1).

51. Tolezano JE, Matsumoto PSS, Taniguchi HH, Bertollo DMB, Pierre MK, Barbosa JEDR, et al. Evaluation of the effectiveness of using deltamethrin- impregnated collars to control visceral leishmaniasis in the municipality of Votuporanga, State of São Paulo, Brazil, 2014 - 2016. Rev Inst Adolfo Lutz. 2018;(VI):110.

52. Dantas-Torres F, Nogueira F dos S, Menz I, Tabanez P, da Silva SM, Ribeiro VM, et al. Vaccination against canine leishmaniasis in Brazil. Int J Parasitol [Internet]. 2020;50(3):171-6. Available from: https://doi.org/10.1016/j.jpara.2020.01.001

53. Gálvez R, Montoya A, Fontal F, Martínez De Murguía L, Miró G. Controlling phlebotomine sand flies to prevent canine Leishmania infantum infection: A case of knowing your enemy. Res Vet Sci [Internet]. 2018;121(April):94-103. Available from: https://doi.org/10.1016/j.rvsc.2018.10.008

54. Mazloumi Gavgani AS, Hodjati MH, Mohite H, Davies CR. Effect of insecticide-impregnated dog collars on incidence of zoonotic visceral leishmaniasis in Iranian children: A matched-cluster randomised trial. Lancet. 2002;360(9330):374-9.

55. Yimam Y, Mohebali M. Effectiveness of insecticide-impregnated dog collars in reducing incidence rate of canine visceral leishmaniasis: A systematic review and meta-analysis. PLoS One [Internet]. 2020;15(9 September 2020):1-15. Available from: http://dx.doi.org/10.1371/journal.pone.0238601

56. Coura-Vital W, Gomes de Almeida Leal G, Marques LA, Da Costa Pinheiro A, Carneiro M, Reis AB. Effectiveness of deltamethrin-impregnated dog collars on the incidence of canine infection by Leishmania infantum: A large scale intervention study in an endemic area in Brazil. PLoS One. 2018;13(12):1-17.

57. De Souza NA, Brazil RP, Araki AS. The current status of the Lutzomyia longipalpis (Diptera: Psychodidae: Phlebotominae) species complex. Mem Inst Oswaldo Cruz. 2017;112(3):161-74.

58. Casanova C, Colla-Jacques FE, Hamilton JGC, Brazil RP, Shaw JJ. Distribution of Lutzomyia longipalpis chemotype populations in São Paulo state, Brazil. PLoS Negl Trop Dis [Internet]. 2015;9(3):e0003620. Available from: http://dx.plos.org/10.1371/journal.pntd.0003620

59. Motoie G, Ferreira GEM, Cupolillo E, Canavez F, Pereira-Chioccola VL. Spatial distribution and population genetics of Leishmania infantum genotypes in São Paulo State, Brazil, employing multilocus 
medRxiv preprint doi: https://doi.org/10.1101/2021.05.18.21257380; this version posted May 22, 2021. The copyright holder for this preprint (which was not certified by peer review) is the author/funder, who has granted medRxiv a license to display the preprint in perpetuity.

It is made available under a CC-BY 4.0 International license.

microsatellite typing directly in dog infected tissues. Infect Genet Evol [Internet]. 2013;18:48-59. Available from: http://dx.doi.org/10.1016/j.meegid.2013.04.031

60. Schwabl P, Boité MC, Bussotti G, Jacobs A, Andersson B, Moreira O, et al. Colonization and genetic diversification processes of Leishmania infantum in the Americas. Commun Biol. 2021;4(1):1-13. 


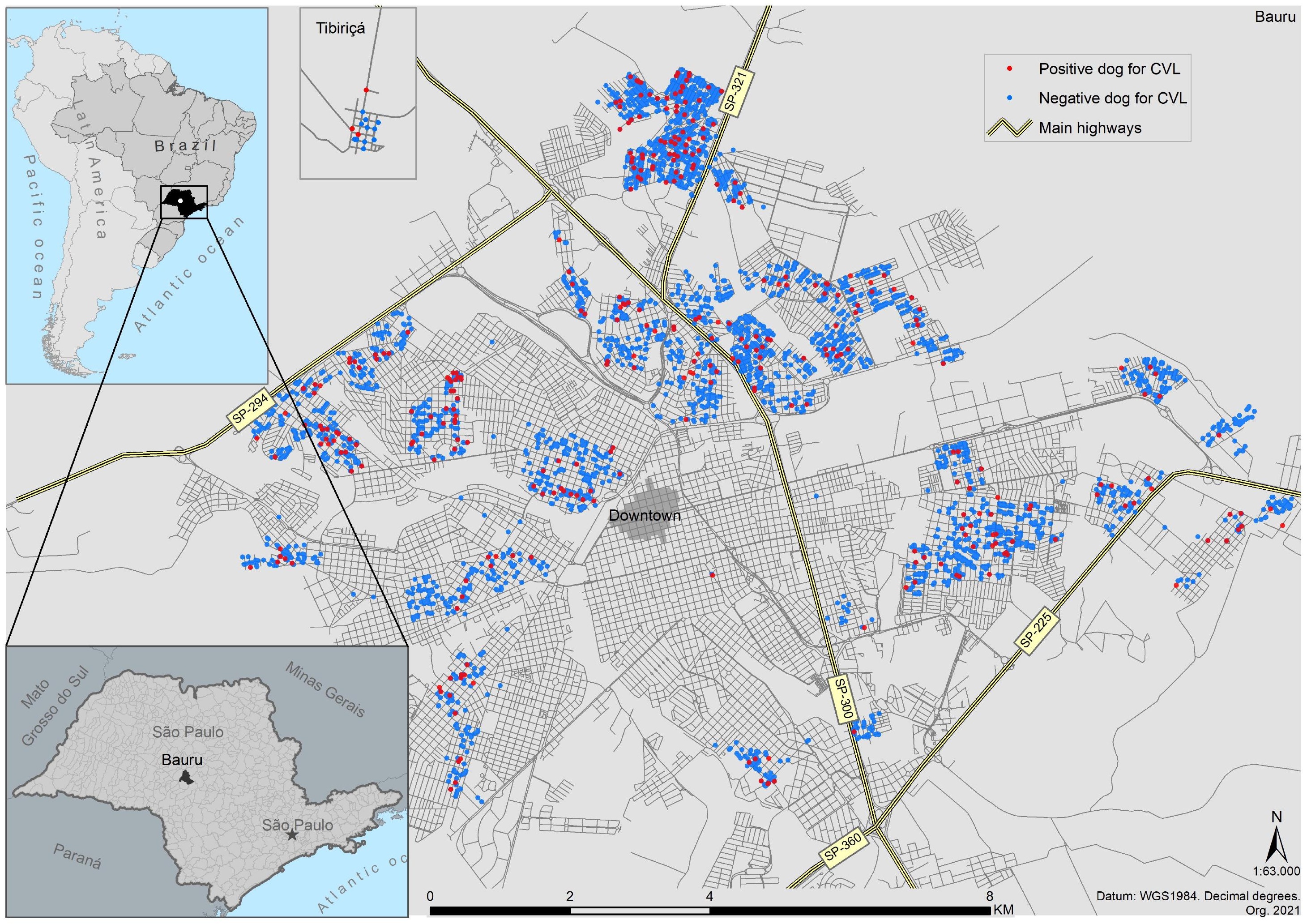




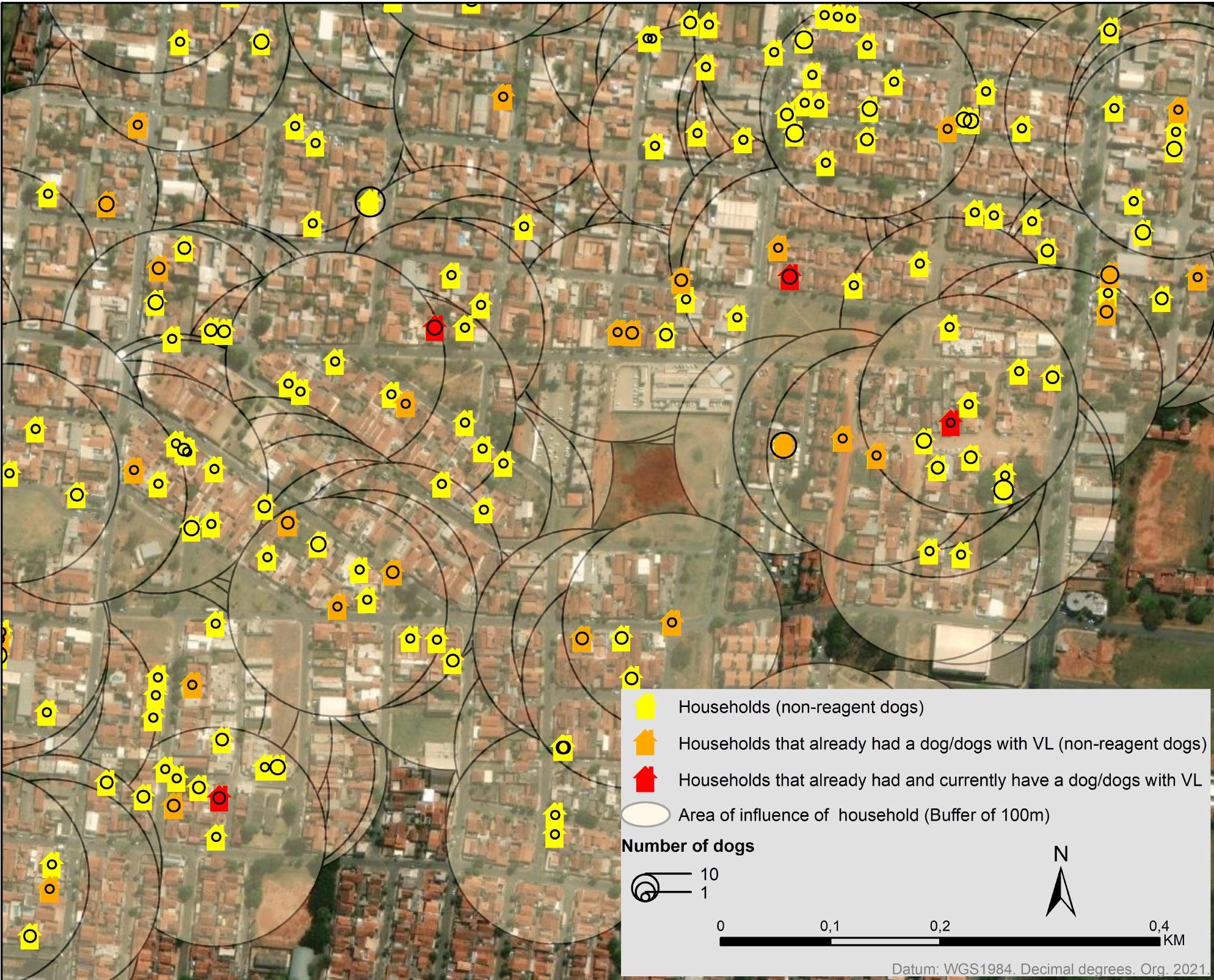




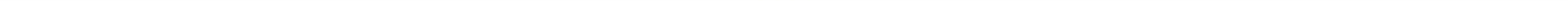




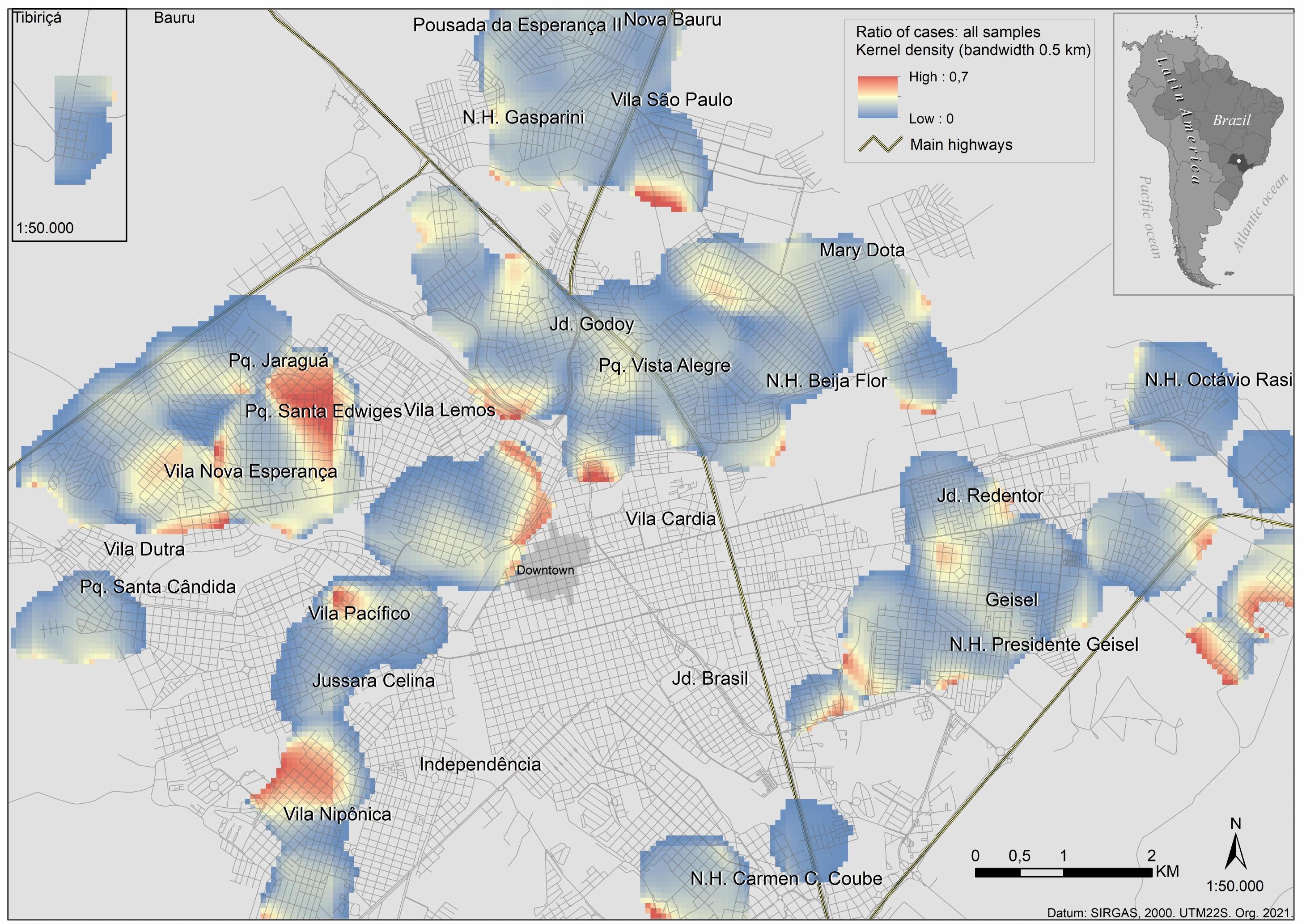


(a)

\section{Prediction}

Kriging (ordinary) $0-0,1$

$0,1-0,2$

$0,2-0,3$

$0,3-0,4$

$0,4-0,5$

$0,5-0,6$

$0,6-0,7$

$0,7-0,8$

$0,8-0,9$

$0,9-1$

Main highways

(b) 


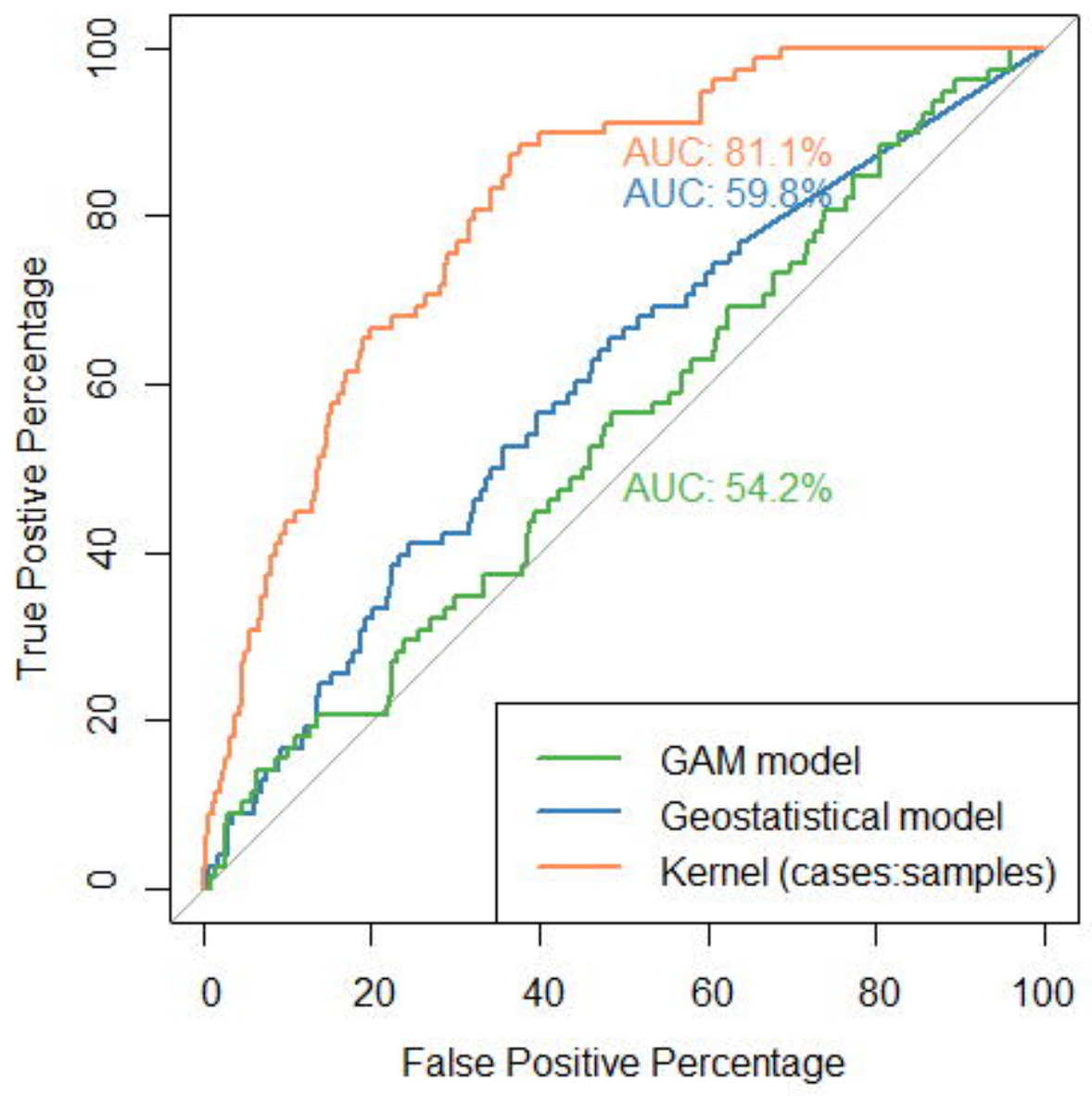


sosa

iv norpigit tors

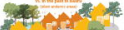

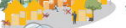

3 然

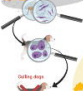

les.ri ho-var Jasa

Y nosarare o verr

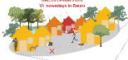

Hoherpilik

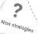
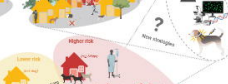

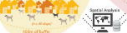

int

का.

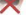

